\title{
Improving the nutritive value and sensory quality of rabbit meat by using leafy vegetables as feedstuffs
}

\author{
Légbé Raïssa Marie Flavienne WOGNIN ${ }^{1}$, Kraidy Athanase OTCHOUMOU ${ }^{1 *}$, Konan \\ Franck YAO ${ }^{1}$ and Sébastien NIAMKE ${ }^{1}$ \\ ${ }^{1}$ Biotechnology Laboratory, Biosciences Faculty, Felix Houphouët Boigny University, 22 BP 582 Abidjan 22 \\ ${ }^{*}$ Corresponding author: OTCHOUMOU Kraidy.Athanase Email: tchoumou2@yahoo.fr
}

Key words: Leafy vegetables, rabbit meat, nutritional value, sensory quality

Submitted 12/12/2017; Accepted 14/03/2018; Publication 29/04/2018.

http://m.elewa.org/Journals/about-japs/

\section{SUMMARY}

The study examined the effect of feeding leafy vegetables on nutritional and sensory qualities of rabbit meat. For this, thirty weaned rabbits of 6 weeks of age (535.24-537.83 g) were allotted to six treatments in a completely randomized design with five replicates. The control diet was a concentrate while treatment diets were a mixture of leafy vegetables and concentrate (50:50; $\mathrm{w} / \mathrm{w})$. The rabbits were housed, fed in individual cages and the experiment was conducted for 9 weeks with 7 days of adaptation. This study revealed that $50 \%$ Abelmoschus esculentus and 50\% Vigna unguiculata leaves combined with $50 \%$ of concentrate diet allowed the highest carcass yield. The meat bone ratio of the rabbits fed with the diets Abelmoschus esculentus and Vigna unguiculata were the highest with $(5.56 \pm 0.15)$ and $(5.40 \pm 0.10)$ respectively. The rabbits fed Vigna unguiculata with concentrate diet presented the highest protein content $(20.92 \%)$. The meat produced by feeding Solanum melongena with concentrate recorded the highest levels of potassium $(546.56 \mathrm{mg} / 100 \mathrm{~g})$ and phosphorus $(336.99 \mathrm{mg} / 100 \mathrm{~g})$. The lysine content of rabbit meat obtained with Solanum melongena diet was higher than other groups. Leafy vegetables supplementation had no significant effect $(P>0.05)$ on the appearance, juiciness and tenderness of rabbit meat. This study showed that Solanum melongena with concentrate mixture allowed the best nutritive value of meat as well as its sensory quality.

\section{INTRODUCTION}

Proteins are indispensable constituents for the growth, maintenance and renewal of tissues and for the synthesis of hormones, enzymes and other molecules essential to the human body (Petsko and Ringe, 2008). The absence of proteins in the diet leads to nutritional deficiencies, which may be severe in the case of animal proteins because of its high biological value. One of the solutions to address the issue of protein deficiency is the breeding of animals that have a short production cycle such as rabbits. The rabbit (Oryctolagus cuniculus) is a monogastric animal with a high reproductive potential (Lebas et al., 1996). Rabbits convert up to $20 \%$ of the protein consumed into meat, more than pigs $(15-18 \%)$ and cattle $(9-12 \%)$ (Suttle, 2010). In comparison to meat of other animal species, rabbit meat is appreciated for its nutritional and dietetic properties, as it is lean, and rich in protein of high biological value (Dalle Zotte, 2000). In addition, rabbits are herbivores, which efficiently convert forages to food. According to Adeyemo et al., (2013), Yao et al., (2016) rabbit perform better when fed with 
mixture of forage and concentrate. Abonyi et al., (2012) and Garza et al., (2012) recommended the use of $50 \%$ of sweet potato leaves to $50 \%$ of commercial pellet in the diets of rabbit weaned for a best growth and decreased a production cost. So, these forages can be provided as supplementary diet to the basic concentrate in order to meet the fiber, vitamins and minerals requirements. In Côte d'Ivoire, a research conducted by several authors (Zoro et al., 2013; Acho et al., 2014; Oulai et al., 2014) indicated that the leafy vegetables had relatively high protein and minerals contents. Kimsé et al., (2014) found

\section{MATERIALS AND METHODS}

3.1 Site of experiment: The experiment was conducted in a traditional rabbit farm in Bingerville municipality (Côte d'Ivoire). The study area is located between $5^{\circ} 21^{\prime} 708$ "North latitude and $3^{\circ} 54^{\prime} 639^{\prime \prime}$ West longitude.

3.2 Experimental diets : Experimental diets consisted of pellets of a balanced concentrate and Vigna unguiculata, Abelmoschus esculentus, Ipomoea batatas, Solanum melongena and Corchorus olitorius leaves. The pellets used in this study were obtained from Ivograin $₫$ Company. Leaves distributed to animals were purchased daily at 7 a.m from markets of Abidjan district. Leafy vegetables were rinsedwith10 L of water containing $2 \mathrm{~mL}$ of sodium hypochlorite $\left(12^{\circ}\right)$ for a few minutes to be disinfected (Kimsé et al., 2013).

3.3 Experimental design: Thirty rabbits $(535 \pm 40 \mathrm{~g})$ from crosses (New Zealand $\mathrm{x}$ Californian) (Martignon et al., 2010), weaned at 35 days of age were housed individually in wirenetting $(70 \times 40 \times 50 \mathrm{~cm})$ raised from $80 \mathrm{~cm}$ to ground. The cages were subjected to natural ventilation and daylight. The average temperature recorded during the experimental period was $29 \pm 2{ }^{\circ} \mathrm{C}$. Water was provided ad libitum. The rabbits were randomly allotted to six (6) dietary treatments with five (5) rabbits per treatment in a completely randomized design. The treatment groups were made up of the following:

Cd: $100 \%$ concentrate diet; that tropical forages added to industrial pellet diet have good impact on rabbit health by reduced sanitary risk index. Recently Yao et al. (2016) reported that theses leafy vegetables could be use in feeding of rabbit as forage to improved health status and growth parameters. However, these studies have not focused on the nutritive value and sensory quality of the rabbit meat. Thus, the present study was undertaken to assess the nutritional quality and sensory characteristics of meat of rabbits fed with leafy vegetables associated with concentrate diet.

SMCd: $50 \%$ of Solanum melongena leaves with 50 $\%$ of concentrate diet;

AECd: $50 \%$ of Abelmoschus esculentus leaves supplemented with $50 \%$ of concentrate diet; COCd: $50 \%$ of Corchorus olitorius leaves supplemented with $50 \%$ of concentrate diet; VUCd: $50 \%$ of Vigna unguiculata leaves supplemented with $50 \%$ of concentrate diet; IBCd: mixture $50 \%$ of Ipomoea batatas leaves with $50 \%$ of concentrate diet. The animals were acclimated to the experimental conditions and diets for seven (7) days (Pérez et al., 1995). During this period, the animals received prophylactic antibiotic treatment. Thus Cocciliumforte ${ }^{\circledR}$ (Amprolium hydrochloride $20 \%$ and $0.2 \%$ vitamin K3) was used in the drinking water at a dose of $15 \mathrm{~g}$ per 15 liters of water for three (3) days to prevent coccidiosis (Kpodékon et al., 2009). After the acclimatization period, the rabbits were fed to satiation with different diets twice daily $(9$ am and $5 \mathrm{pm}$ ) until the age of 98 days. Feed intake was determined as the difference between the feed supplied and left over for each replicate per day.

3.4 Slaughtering and sampling: At the age of 98 days, all rabbits were weighted to determine their final live weight and slaughtered for evaluating meat quality and sensorial characteristics. The carcass of each animal was weighed before the abdominal fat was removed and weighed. Abdominal fat was expressed as percentage of the carcass weight, while carcass 
yield was obtained by calculating the ratio between the carcass weight and final live weight. The carcass without head was divided according to the method described by Blasco and Ouhayoun (1996). The carcass was cut between the last thoracic and the first lumbar vertebrae and between the 6th and 7th lumbar vertebrae. One of hind limb from each carcass was dissected for the estimation of the meat to bone ratio. The other hind leg was stored at $4{ }^{\circ} \mathrm{C}$ for $24 \mathrm{~h}$ for sensory evaluation. After the carcass measurements evaluation, all the meat pieces were separated from the bone, minced, well mixed and vacuum-packed and frozen at $-18{ }^{\circ} \mathrm{C}$ until the chemical analysis.

\subsection{Determination of chemical} composition of meat: Meat chemical composition was determined according to the procedures of AOAC (1990). Moisture content of meat samples $(2 \mathrm{~g})$ was determined by oven drying at $105^{\circ} \mathrm{C}$ for 24 hours until a constant weight. The ash content was obtained by mineralization of $10 \mathrm{~g}$ of meat samples in a muffle furnace set at $550^{\circ} \mathrm{C}$ for $12 \mathrm{~h}$. Crude protein was calculated as nitrogen amount (Kjeldhal method) multiplied by 0.625 per $100 \mathrm{~g}$ of meat. Fat from meat samples was determined with Soxhlet extraction method using petroleum ether as solvent.

3.6 Minerals analysis: Ten (10) g of the processed samples were subjected to dry ashing in a well-cleaned porcelain crucible at $550{ }^{\circ} \mathrm{C}$ in a muffle furnace (Pyrolabo, France). The resultant ash was dissolved in $5 \mathrm{~mL}$ acid mix of $\mathrm{HCl} / \mathrm{HNO}_{3}$. The mineral composition was determined using atomic absorption spectrophotometer (AAS model, SP9).

3.6.1 Determination of essential amino acids: Amino acids were determined by the procedures of ISO (2005). Five (5) grams of rabbit meat were hydrolyzed in $10 \mathrm{~mL}$ of $6 \mathrm{~N}$ hydrochloric acid at $110^{\circ} \mathrm{C}$ for 24 hours. The hydrolysates were diluted in $20 \mathrm{ml}$ of $0.2 \mathrm{~N}$ sodium citrate, $\mathrm{pH}$ 2.3. After evaporation of acid, the sample was recovered in $10 \mathrm{~mL}$ of $70 \%$ ethanol, filtered on a millipore filter paper and 2 $\mathrm{mL}$ of each sample were injected in high performance liquid chromatography chain. This chain included a Waters Alliance unit, model e2695 equipped with two Lichrocart 125-4 Lichrospher 100 RP-18 columns in series. Each column was $12.5 \mathrm{~cm}$ long and $5 \mu \mathrm{m}$ in diameter. Elution was done in gradient mode with a flow rate of $1 \mathrm{~mL} / \mathrm{min}$. Detection was carried out using a Waters spectrofluorometer 2475. Excitation and emission were carried out respectively at $340 \mathrm{~nm}$ and $450 \mathrm{~nm}$.

3.6.2 Determination of vitamins: The vitamin content of the samples was determined by high performance liquid chromatography technique using the method described by European pharmacopoeia book (2014).

\subsubsection{Determination of vitamins $A$ and}

E: Alpha-tocopherol and retinol were analyzed by an HPLC system (SHIMADZU SPD 20A) with DAD detector, a high-pressure pump and a C18 column ODS, 250x4.60 $\mathrm{mm}$ (Cluzeau, France). The mobile phase consisted of acetonitrile and methanol, and a flow rate of 1.5 $\mathrm{mL} / \mathrm{min}$ was used. Alpha-tocopherol and retinol were identified by using UV detector and comparing the samples' retention time with the pure standards. The quantification was carried out using by comparing the area sample peak with that of the reference standards, which are retinol acetate and alpha-tocopherol. Before injection into the HPLC system, $5 \mathrm{~g}$ of samples were crushed in $25 \mathrm{~mL}$ of methanolic solution. The filtrate collected was used to evaluate the levels of vitamins.

\subsubsection{Determination of water soluble} vitamins: Two (2) grams of sample were placed in $25 \mathrm{~mL}$ of acid sulphuric $(0.1 \mathrm{~N})$ solution. Then, the contents were adjusted to $\mathrm{pH} 4.5$ with $2.5 \mathrm{M}$ sodium acetate. The preparation was stored at $35^{\circ} \mathrm{C}$ overnight. The mixture was then filtered through a Whatman paper and the filtrate was diluted with $50 \mathrm{~mL}$ of pure water and filtered again through a micropore filter $(0.45$ $\mu \mathrm{m})$. Twenty microliters $(20 \mu \mathrm{l})$ of the filtrate were injected into the HPLC system. Quantification of vitamins B5, B6, B9 and B12 content was accomplished by comparison to standards. Chromatographic separation was achieved on a reversed phase (RP) HPLC column through the isocratic delivery mobile 
phase at a flow rate of $1.5 \mathrm{~mL} / \mathrm{min}$. Ultraviolet (UV) absorbance was recorded at $270 \mathrm{~nm}$ at room temperature.

3.7 Sensory evaluation: The hind limb from each treatment group was used for sensory evaluation after cooking without salt or spice on charcoal for 20 to 25 minutes. The meat samples were cut into pieces and served to15 people randomly chosen to avoid location effects. These people were trained to evaluate the meat sensory quality by using 5 descriptors (appearance, taste, juiciness, texture,

\section{RESULTS AND DISCUSSION}

The results indicated variations in crude protein, crude lipid, ash and minerals among the five vegetables species and industrial diet (Table 1). Corchorus olitorius and Vigna unguiculata leaves recorded the highest crude protein $(\mathrm{P}<0.05)$ respectively $18.31 \pm 0.29 \mathrm{~g} / 100 \mathrm{~g}$ and 19.15 $\pm 0.32 \mathrm{~g} / 100 \mathrm{~g}$. These protein levels respect the $16 \%$ of proteins recommended by Lebas (1989). Corchorus olitorius and Vigna unguiculata leaves have more than adequate levels of the nutrients to meet crude protein requirements of rabbit growth. These leafy vegetables can be protein source for feed formulation for growing rabbit. The crude lipid ranged from $3.67 \mathrm{~g} / 100 \mathrm{~g}$ to 5.29 $\mathrm{g} / 100 \mathrm{~g}$ for leafy vegetables and industrial diets. These values were within the range reported by Lebas (1989) which recommended 3-5 g/100 g of fat for young rabbit's diets to cover energy needs. Ash content was higher $(\mathrm{P}<0.05)$ in Ipomoea batatas $(14.24 \%)$, Solanum melongena $(14.05 \%)$ followed by Abelmoschus esculentus acceptability) according to a ranking test of intensity level (1= lesser; $3=$ greater) of each descriptor. Descriptors were made up of the following (Akinnusif et al., 2007)

Appearance: fatty, lean

Juiciness: juicy, dry

Taste: salty, bland

Texture: tender, tough

3.8 Statistical analysis: Data were analyzed by using the SPSS17software. Differences between means were separated using Duncan Multiple Range Test (Duncan, 1955).

leaves $(10.69 \%)$. The same trend was observed to minerals analysis in which Ipomoea batatas and Solanum melongena had the highest levels of minerals. Table 1 showed that calcium $(3312.70$ $\pm 60.93 \mathrm{mg} / 100 \mathrm{~g})$ and iron (115.54 \pm 5.09 $\mathrm{mg} / 100 \mathrm{~g}$ ) in Solanum melongena were significantly $(p<0.05)$ higher. Except iron and sodium which values were lower, the leaves of Ipomoea batatas indicated averages twice than those obtained for Abelmoschus esculentus, Corchorus olitorius, Vigna unguiculata and concentrate diet. High amounts of minerals especially for calcium and phosphorus could increase growth performance of rabbits because there plays a key role in organic processes, such as heart function, muscle contraction and involved in energy metabolism. In addition, the recorded levels related to the calcium to phosphorus ratio of $1.5: 1$ to $2: 1$ recommended by de Blas and Wiseman (2003) for a best growth. 
Table 1: Nutrients contents of leafy vegetables and concentrate diet (\% Dry matter)

\begin{tabular}{l|l|l|l|l|l|l}
\hline & \multicolumn{2}{l}{ Leafy vegetables and Concentrate diet } \\
\hline Nutrients & $\begin{array}{l}\text { Solanum } \\
\text { melongena }\end{array}$ & $\begin{array}{l}\text { Abelmoschus } \\
\text { esculentus }\end{array}$ & $\begin{array}{l}\text { Corchorus } \\
\text { olitorius }\end{array}$ & $\begin{array}{l}\text { Ipomoea } \\
\text { batatas }\end{array}$ & $\begin{array}{l}\text { Vigna } \\
\text { unguiculata }\end{array}$ & $\begin{array}{l}\text { Concentr } \\
\text { ate diet }\end{array}$ \\
\hline $\begin{array}{l}\text { Dry matter } \\
(\mathrm{g} / 100 \mathrm{~g})\end{array}$ & 24.75 & 19.66 & 24.28 & 21.03 & 20.76 & 89.39 \\
$\pm 0.11 \mathrm{c}$ & $\pm 0.17 \mathrm{a}$ & $\pm 0.19 \mathrm{c}$ & $\pm 0.20 \mathrm{~b}$ & $\pm 0.21 \mathrm{~b}$ & $\pm 0.00 \mathrm{~d}$ \\
\hline Crude protein & 12.55 & 10.58 & 18.31 & 15.83 & 19.15 & 14.63 \\
$(\mathrm{~g} / 100 \mathrm{~g})$ & $\pm 0.24 \mathrm{~b}$ & $\pm 0.64 \mathrm{a}$ & $\pm 0.29 \mathrm{e}$ & $\pm 0.41 \mathrm{~d}$ & $\pm 0.32 \mathrm{e}$ & $\pm 0.18 \mathrm{c}$ \\
\hline Lipids & 3.67 & 4.42 & 4.76 & 3.75 & 5.29 & 3.68 \\
$(\mathrm{~g} / 100 \mathrm{~g})$ & $\pm 0.12 \mathrm{a}$ & $\pm 0.20 \mathrm{~b}$ & $\pm 0.05 \mathrm{c}$ & $\pm 0.14 \mathrm{a}$ & $\pm 0.02 \mathrm{~d}$ & $\pm 0.02 \mathrm{a}$ \\
\hline Ash & 14.05 & 10.69 & 8.10 & 14.24 & 9.93 & 8.38 \\
$(\mathrm{~g} / 100 \mathrm{~g})$ & $\pm 0.09 \mathrm{~d}$ & $\pm 0.18 \mathrm{c}$ & $\pm 0.23 \mathrm{a}$ & $\pm 0.24 \mathrm{~d}$ & $\pm 0.28 \mathrm{~b}$ & $\pm 0.10 \mathrm{~b}$ \\
\hline Calcium & 3312.7 & 1325.14 & 1019.72 & 1938.54 & 1512.96 & 980.30 \\
$(\mathrm{mg} / 100 \mathrm{~g})$ & $\pm 60.93 \mathrm{e}$ & $\pm 64.87 \mathrm{~b}$ & $\pm 44.64 \mathrm{a}$ & $\pm 30.05 \mathrm{~d}$ & $\pm 71.05 \mathrm{c}$ & $\pm 14.88 \mathrm{a}$ \\
\hline $\begin{array}{l}\text { Iron } \\
(\mathrm{mg} / 100 \mathrm{~g})\end{array}$ & 115.54 & \pm 3.80 & 35.44 & 17.66 & 52.22 & 97.84 \\
\hline Potassium & 3095.7 & 401.88 & 1328.9 & 5103.48 & 1986.94 & 3919.26 \\
$(\mathrm{mg} / 100 \mathrm{~g})$ & $\pm 69.20 \mathrm{~d}$ & $\pm 39.95 \mathrm{a}$ & $\pm 85.43 \mathrm{~b}$ & $\pm 51.99 \mathrm{f}$ & $\pm 72.91 \mathrm{c}$ & $\pm 59.48 \mathrm{e}$ \\
\hline Magnesium & 244.65 & 233.81 & 106.29 & 387.73 & 196.41 & 188.77 \\
$(\mathrm{mg} / 100 \mathrm{~g})$ & $\pm 10.50 \mathrm{c}$ & $\pm 12.03 \mathrm{c}$ & $\pm 7.26 \mathrm{a}$ & $\pm 6.01 \mathrm{~d}$ & $\pm 11.54 \mathrm{~b}$ & $\pm 2.86 \mathrm{~b}$ \\
\hline Phosphorus & 1257.22 & 384.04 & 501.62 & 1804.32 & 633.7 & 693.08 \\
$(\mathrm{mg} / 100 \mathrm{~g})$ & $\pm 24.95 \mathrm{~d}$ & $\pm 62.64 \mathrm{a}$ & $\pm 19.63 \mathrm{~b}$ & $\pm 27.93 \mathrm{e}$ & $\pm 31.40 \mathrm{c}$ & $\pm 10.52 \mathrm{c}$ \\
\hline Sodium & 88.93 & 62.65 & 51.26 & 50.66 & 61.78 & 81.23 \\
$(\mathrm{mg} / 100 \mathrm{~g})$ & $\pm 4.01 \mathrm{c}$ & $\pm 5.22 \mathrm{~b}$ & $\pm 3.80 \mathrm{a}$ & $\pm 0.80 \mathrm{a}$ & $\pm 4.45 \mathrm{~b}$ & $\pm 1.23 \mathrm{c}$ \\
\hline Zinc & 8.47 & 1.99 & 0.43 & 28.13 & 0.21 & 5.27 \\
$(\mathrm{mg} / 100 \mathrm{~g})$ & $\pm 0.34 \mathrm{~d}$ & $\pm 0.12 \mathrm{~b}$ & $\pm 0.10 \mathrm{a}$ & $\pm 0.43 \mathrm{e}$ & $\pm 0.08 \mathrm{a}$ & $\pm 0.08 \mathrm{c}$ \\
\hline Copper & 82.07 & 7.45 & 20.01 & 127.41 & 5.39 & 41.73 \\
$(\mathrm{mg} / 100 \mathrm{~g})$ & $\pm 3.18 \mathrm{~d}$ & $\pm 1.38 \mathrm{a}$ & $\pm 0.96 \mathrm{~b}$ & $\pm 9.55 \mathrm{e}$ & $\pm 1.69 \mathrm{a}$ & $\pm 0.63 \mathrm{c}$ \\
\hline
\end{tabular}

${ }_{\mathrm{a}, \mathrm{b}}$ values in the same row with different superscripts differ at $5 \%(\mathrm{P}<0.05)$

The essential amino acids and vitamins contents of experimental diets are presented in Table 2. The most abundant amino acid in diets was leucine, which ranged from 8.91 to $9.41 \mathrm{~g} / 100 \mathrm{~g}$ protein for Corchorus olitorius and Solanum melongena, respectively. Proportion of threonine in Solanum melongena leaf $(1.83 \mathrm{~g} / 100 \mathrm{~g})$ is lower than those of other, while Ipomoea batatas had the lowest content of lysine $(2.56 \mathrm{~g} / 100 \mathrm{~g}$ protein) and tyrosine (2.34g / $100 \mathrm{~g}$ protein). Corchorus olitorius leaf recorded amino acid concentrations almost similar to those obtained in concentrate diet. Despite the differences noted, amino acid concentrations in leaves and concentrate diet were higher than the proportions required for a growing young rabbit. According to Lebas (1989), young rabbit needs $0.70 \mathrm{~g} / 100 \mathrm{~g}$ of lysine, 1.05 of leucine, $0.7 \mathrm{~g} / 100 \mathrm{~g}$ of valine and $0.55 \mathrm{~g} / 100 \mathrm{~g}$ of threonine for growth. The evaluation of vitamin contents in leaves and concentrate revealed that Abelmoschus esculentus contained highest levels of provitamin A $(197.99 \mu \mathrm{g} / 100 \mathrm{~g})$ and B6 (155.69 $\mu / 100 \mathrm{~g})$. The lowest percentage of provitamin A was obtained with Vigna unguiculata, whose leaves were characterized by high concentrations of vitamin B5 (94.99 $\mu \mathrm{g} / 100 \mathrm{~g})$ and B12 (31.37 $\mu \mathrm{g} / 100$ g). For Solanum melongena leaf the vitamin B9 was estimated to $275.2 \mu \mathrm{g} / 100 \mathrm{~g}$ and was higher than the proportions of other leafy vegetables 
and commercial pellets. In this study, the vitamin levels recorded were low compared to the values required to meet the animal's needs. Also, the amounts of proteins, vitamins in some leaves being low and the absence of vitamin $\mathrm{E}$ in all leafy vegetables, compared to the values recommended for best growth performances may retard growth if the animal does not feed to satiety.

Table 2: Essential amino acids and vitamins contents of leafy vegetables and concentrate diet (\% Dry matter)

\begin{tabular}{|c|c|c|c|c|c|c|}
\hline \multirow[b]{2}{*}{ Nutrients } & \multicolumn{6}{|c|}{ Leafy vegetables and Concentrate diet } \\
\hline & $\begin{array}{c}\text { Solanum } \\
\text { melongena }\end{array}$ & $\begin{array}{c}\text { Abelmoschus } \\
\text { esculentus }\end{array}$ & $\begin{array}{c}\text { Corchorus } \\
\text { olitorius }\end{array}$ & $\begin{array}{c}\text { Ipomoea } \\
\text { batatas }\end{array}$ & $\begin{array}{c}\text { Vigna } \\
\text { unguiculata }\end{array}$ & $\begin{array}{c}\text { Concentrate } \\
\text { diet }\end{array}$ \\
\hline \multicolumn{7}{|c|}{ Amino acids $(\mathrm{g} / 100 \mathrm{~g})$} \\
\hline Phenylalanine & 4.56 & 3.86 & 2.84 & 3.51 & 3.65 & 2.85 \\
\hline Leucine & 9.41 & 9.33 & 8.91 & 4.16 & 9.16 & 9.25 \\
\hline Threonine & 1.83 & 4.40 & 4.51 & 3.24 & 4.36 & 4.02 \\
\hline Valine & 6.17 & 5.21 & 3.98 & 4.07 & 4.1 & 4.04 \\
\hline Lysine & 8.72 & 7.70 & 4.69 & 2.56 & 5.03 & 4.65 \\
\hline Methionine & 0.97 & 0.72 & 1.42 & 1.37 & 1.4 & 1.37 \\
\hline Tyrosine & 3.24 & 4.88 & 4.70 & 2.34 & 4.88 & 4.66 \\
\hline \multicolumn{7}{|l|}{ Vitamins $(\mu \mathrm{g} / 100 \mathrm{~g})$} \\
\hline Vitamin A & 104.86 & 197.99 & 144.54 & 143.15 & 28.5 & 115.74 \\
\hline Vitamin E & $\mathrm{Nd}$ & $\mathrm{Nd}$ & $\mathrm{Nd}$ & $\mathrm{Nd}$ & $\mathrm{Nd}$ & $\mathrm{Nd}$ \\
\hline Vitamin B5 & 42.94 & 20.4 & 35.86 & 24.7 & 94.99 & 27.27 \\
\hline Vitamin B6 & 15.19 & 155.69 & 69.09 & 18.4 & 41.7 & 36.99 \\
\hline Vitamin B9 & 275.2 & 122.75 & 92.68 & 101.1 & 202.58 & 124.32 \\
\hline Vitamin B12 & 5.99 & 17.79 & 21.04 & 9.1 & 31.37 & 21.56 \\
\hline
\end{tabular}

$\mathrm{Nd}:$ Non detected

Table 3: Average feed and nutrient intakes (g/day/rabbit) of rabbits fed with concentrate diet and leafy vegetables

\begin{tabular}{l|c|c|c|c|c|c}
\hline & \multicolumn{7}{|c}{ Treatments } \\
\hline Parameters & SMCd & AECd & COCd & IBCd & VUCd & Cd \\
\hline Forages intake & 198.04 & 179.71 & 191.25 & 232.29 & 192.08 & 0.00 \\
& $\pm 15.38 \mathrm{c}$ & $\pm 10.66 \mathrm{~b}$ & $\pm 8.60 \mathrm{bc}$ & $\pm 3.77 \mathrm{~d}$ & $\pm 9.14 \mathrm{bc}$ & $\pm 0.00 \mathrm{a}$ \\
\hline & 67.98 & 73.99 & 70.66 & 68.33 & 70.53 & 107.9 \\
Pellet intake & $\pm 1.14 \mathrm{a}$ & $\pm 1.48 \mathrm{~b}$ & $\pm 1.00 \mathrm{a}$ & $\pm 0.63 \mathrm{a}$ & $\pm 2.39 \mathrm{a}$ & $\pm 3.93 \mathrm{c}$ \\
\hline & 266.02 & 253.70 & 261.91 & 300.62 & 262.61 & 107.9 \\
Total feed intake & $\pm 15.95 \mathrm{~b}$ & $\pm 11.90 \mathrm{~b}$ & $\pm 8.17 \mathrm{~b}$ & $\pm 4.37 \mathrm{c}$ & $\pm 10.58 \mathrm{~b}$ & $\pm 3.93 \mathrm{a}$ \\
\hline & 15.04 & 13.41 & 18.44 & 16.67 & 17.10 & 14.11 \\
protein intake & $\pm 0.13 \mathrm{c}$ & $\pm 0.29 \mathrm{a}$ & $\pm 0.37 \mathrm{e}$ & $\pm 0.20 \mathrm{~d}$ & $\pm 0.60 \mathrm{~d}$ & $\pm 0.51 \mathrm{~b}$ \\
\hline & 4.04 & 4.00 & 4.72 & 4.08 & 4.43 & 3.55 \\
Lipids intake & $\pm 0.04 \mathrm{~b}$ & $\pm 0.90 \mathrm{~b}$ & $\pm 0.10 \mathrm{~d}$ & $\pm 0.05 \mathrm{~b}$ & $\pm 0.16 \mathrm{c}$ & $\pm 0.13 \mathrm{a}$ \\
\hline & 12.07 & 9.32 & 9.36 & 11.98 & 9.24 & 8.08 \\
Ash intake & $\pm 0.11 \mathrm{c}$ & $\pm 0.21 \mathrm{~b}$ & $\pm 0.16 \mathrm{~b}$ & $\pm 0.16 \mathrm{c}$ & $\pm 0.32 \mathrm{~b}$ & $\pm 0.29 \mathrm{a}$ \\
\hline
\end{tabular}

${ }_{\mathrm{a}, \mathrm{b}}$ values in the same row with different superscripts differ at $5 \%(\mathrm{P}<0.05)$

Table 3 and Table 4 showed the daily nutrient intake, final weight and carcass characteristics respectively. The final weight and carcass characteristics were affected by nutrients intake. The highest weight gains were obtained with the groups fed to SMCd (1371.98 $39.75 \mathrm{~g})$ and 
IBCd (1415.83 $\pm 51.57 \mathrm{~g})$ which rabbit intake more amounts of protein and minerals. The increase of weight gain with these two diets could be due to proteins and calcium, which contributed in construction of rabbit body and represent major components of the skeletal system, are cofactors of several enzymatic reactions, involved in nerve transmissions and acid-base regulation of blood and other body fluids. The same result was reported by Abonyi et al., (2012) who observed that rabbits fed with concentrate supplemented with sweet potato leaves had a growth rate similar to rabbits feeding only concentrate diet. These leaves can be recommended to breeders to promote good growth of rabbits. Low minerals intake associated with high proteins and lipids intake have allowed to final weight also high with COCd diet. These results could be explained by good balance between the components of diet because Ouhayoun and Delmas (1983) and Trocino et al., (2000) showed that protein / energy ratio and energy level are important factors that may increase weight gain. These factors could help to understand the high weight gains observed with the control diet. Although beneficial to the animal, the presence of some constituents in leaves could also reduce the bioavailability of nutrients, which would have a negative influence on growing rabbit and quality of the meat. It noted data recorded for carcass characteristics (carcass weight and abdominal fat) are not in agreement with the results by Renouf and offner (2007), Fernandez, and Fraga (1996) which demonstrated that low and moderate increase carcass yield and the amount of dissectible fat. Despite the presence of diets with lower weight gains, all experimental diets had given at the end of the experiment, carcasses with characteristics similar to those described by Ouhayoun et al., (1986). According these authors, the commercial carcass should weigh $1285 \mathrm{Kg}$ with a carcass yield of $57 \%$.

Table 4: Effect of leafy vegetables on the carcass characteristics of rabbit fed with leafy vegetables and concentrate diet

\begin{tabular}{l|c|c|c|c|c|c}
\hline & \multicolumn{6}{c}{ Treatments } \\
\hline Parameters & SMCd & AECd & COCd & IBCd & VUCd & Cd \\
\hline Initial & 535.24 & 534.54 & 532.09 & 535.46 & 533.91 & 537.83 \\
weight (g) & $\pm 40.82 \mathrm{a}$ & $\pm 40.55 \mathrm{a}$ & $\pm 40.83 \mathrm{a}$ & $\pm 39.35 \mathrm{a}$ & $\pm 40.68 \mathrm{a}$ & $\pm 39.83 \mathrm{a}$ \\
\hline Final & 1910.76 & 1794.84 & 1927.76 & 1948.91 & 1817.11 & 1907.45 \\
weight (g) & $\pm 52.79 \mathrm{bc}$ & $\pm 60.51 \mathrm{a}$ & $\pm 65.21 \mathrm{c}$ & $\pm 93.47 \mathrm{c}$ & $\pm 50.61 \mathrm{ab}$ & $\pm 72.60 \mathrm{bc}$ \\
\hline Weight & 1371.98 & 1257.82 & 1402.41 & 1415.83 & 1287.72 & 1369.82 \\
gain (g) & $\pm 39.75 \mathrm{~b}$ & $\pm 31.87 \mathrm{a}$ & $\pm 20.60 \mathrm{~b}$ & $\pm 51.57 \mathrm{~b}$ & $\pm 51.27 \mathrm{a}$ & $\pm 71.20 \mathrm{~b}$ \\
\hline Carcass & 1228.89 & 1192.59 & 1255.42 & 1239.48 & 1185.00 & 1302.90 \\
weight (g) & $\pm 25.21 \mathrm{ab}$ & $\pm 24.93 \mathrm{a}$ & $\pm 21.73 \mathrm{ab}$ & $\pm 61.95 \mathrm{ab}$ & $\pm 30.16 \mathrm{a}$ & $\pm 27.60 \mathrm{ab}$ \\
\hline Carcass & 64.25 & 64.52 & 63.72 & 62.35 & 64.66 & 61.92 \\
yield (\%) & $\pm 0.75 \mathrm{bc}$ & $\pm 0.17 \mathrm{c}$ & $\pm 0.99 \mathrm{abc}$ & $\pm 0.43 \mathrm{ab}$ & $\pm 0.18 \mathrm{c}$ & $\pm 1.31 \mathrm{a}$ \\
\hline Meat/ bone & 4.48 & 5.56 & 4.77 & 3.98 & 5.40 & 4.87 \\
ratio & $\pm 0.15 \mathrm{~b}$ & $\pm 0.15 \mathrm{~d}$ & $\pm 0.09 \mathrm{bc}$ & $\pm 0.09 \mathrm{a}$ & $\pm 0.10 \mathrm{~d}$ & $\pm 0.17 \mathrm{c}$ \\
\hline Abdominal & 1.64 & 1.53 & 1.78 & 2.62 & 2.84 & 2.78 \\
fat (\%) & $\pm 0.19 \mathrm{a}$ & $\pm 0.48 \mathrm{a}$ & $\pm 0.41 \mathrm{a}$ & $\pm 0.19 \mathrm{~b}$ & $\pm 0.12 \mathrm{~b}$ & $\pm 0.46 \mathrm{~b}$ \\
\hline
\end{tabular}

${ }_{\mathrm{a}, \mathrm{b}}$ values in the same row with different superscripts differ at $5 \%(\mathrm{P}<0.05)$

Effects of experimental diets nutritional quality of rabbit's meat were summarized in table 5 and 6. The dry matter, protein, ash, lipids and minerals were significantly affected $(\mathrm{P}<0.05)$ by treatments. Crude protein was significantly higher $(\mathrm{P}<0.05)$ for diets that include leaves of
Corchorus olitorius (20.56 $\pm 0.65 \mathrm{~g} / 100 \mathrm{~g})$, Ipomoea batatas (19.83 \pm 1.48$)$ and Vigna unguiculata $(20.92 \pm 0.32 \mathrm{~g} / 100 \mathrm{~g})$. The higher proportion of proteins in rabbit meat could be explained by the presence of significant levels of proteins in forages use to fed animals. Indeed, ability of the 
rabbit to convert $20 \%$ of the proteins ingested to meat, which is an asset that makes it possible to optimize the use of leafy vegetables in breeding. This is in agreement with the values reported by Nguyen and Nguyen (2008) after using sweet potato leaves as forage in rabbit feed. In addition, the ingestion of $100 \mathrm{~g}$ of rabbit meat obtained from experimental diets would contribute significantly to the recommended nutritional intakes of protein, which are estimated at $0.83 \mathrm{~g} / \mathrm{kg} / \mathrm{day}$ for human according to AFSSA (2007). The diets including respectively Solanum melongena leaves $(3.63 \pm 0.13$ $\mathrm{g} / 100 \mathrm{~g})$ and Ipomoea batatas $(3.66 \pm 0.08 \mathrm{~g} / 100 \mathrm{~g})$ recorded the highest ash content. The same trend was observed for mineral contents in rabbit meat obtained with the mixture of Solanum melongena or Ipomoea batatas and concentrate diet. Results indicated that meat contained higher calcium, potassium, phosphorus, magnesium and copper while theses minerals were lower for rabbit meat fed with control diet. Similar effect was obtained by Doukoupilová et al., (2007), which showed that hind leg meat of rabbits fed the selenium-supplemented diet contained four times more selenium than meat of control rabbits. Crude lipid levels estimated to be less than $10 \%$ in the muscles are similar to percentage recorded by many authors. This lowfat content allows some authors as Gigaud and Combes (2007) to describe rabbit meat as dietetic food.

Except phenylalanine $(0.71 \pm 0.05 \mathrm{~g} / 100 \mathrm{~g})$ and tyrosine $(1.42 \pm 0.11 \mathrm{~g} / 100 \mathrm{~g})$ values, the other amino acids were significantly $(\mathrm{p}<0.05)$ low for mixture of Ipomoea batatas leaf with concentrate diet. Essential amino acid averages revealed that valine, lysine and methionine contents of rabbit meat fed to Solamun melongena and concentrate were significant $(p<0.05)$ higher than meat obtained with other diets. The combination of Solanum melongena leaves with concentrate diet was characterized by the highest proportion of fat-soluble vitamins. Data provided in table 6 indicated that vitamin $\mathrm{A}$ content decreased significantly $(\mathrm{P}<0.05)$ when the leaves of Vigna unguiculata were used in rabbit's diet. Except for vitamin B12, proportions of vitamins B5 $(1425.63 \mu \mathrm{g} / 100 \mathrm{~g}), \mathrm{B} 6(355.00 \mu \mathrm{g} / 100 \mathrm{~g})$ and B9 $(11.46 \mu \mathrm{g} / 100 \mathrm{~g})$ obtained from the control diet were higher than those of experimental diets. These results confirm the capacity of rabbit to convert efficiently feed consommed. It was demonstrated by several studies, including Simonová et al., (2010) which reported that oregano (Origanum vulgare) and sage (Salvia officinalis) extracts as well as Eleutherococcus senticosus could be involved in rabbit's diet to in improve amino acid composition of rabbit meat. The lower concentration of amino acids observed for meat derived to IBCd diet could be attributed to low contents of amino acids in Ipomoea batatas leaves. These results matched with Adel et al., (2017) paper where it is shows those amino acid contents of feed influence composition of amino acids of meat rabbit. Amino acid and vitamin concentrations of rabbit meat obtained from experimental diets could cover at least $50 \%$ of the recommended human nutritional intake according to the data provided by AFSSA (2007). All data revealed that vegetables are good source of nutrients and could be used for manufacture of pellet feed. 
Table 5: Effect of partial substitution of concentrate diet to leafy vegetables on macronutrients and minerals contents of meat rabbit

\begin{tabular}{|c|c|c|c|c|c|c|}
\hline \multirow[b]{2}{*}{ Parameters } & \multicolumn{6}{|c|}{ Treatments } \\
\hline & SMCd & AECd & COCd & IBCd & VUCd & $\mathrm{Te}$ \\
\hline \multicolumn{7}{|c|}{ Macronutrients (g/100 g) } \\
\hline $\begin{array}{l}\text { Dry matter } \\
\text { Crude }\end{array}$ & $29.58 \pm 0.62 d$ & $25.80 \pm 0.59 \mathrm{a}$ & $26.72 \pm 0.64 \mathrm{ab}$ & $26.06 \pm 0.51 \mathrm{a}$ & $28.56 \pm 0.54 \mathrm{~cd}$ & $27.83 \pm 1.00 \mathrm{bc}$ \\
\hline & $19.07 \pm 1.50 \mathrm{ab}$ & $19.16 \pm 0.86 \mathrm{ab}$ & $20.56 \pm 0.65 b$ & $19.83 \pm 1.48 b$ & $20.92 \pm 0.32 b$ & $16.54 \pm 0.32 \mathrm{a}$ \\
\hline Crude lipid & $6.73 \pm 0.25 b$ & $6.03 \pm 0.17 \mathrm{a}$ & $6.64 \pm 0.17 \mathrm{~b}$ & $7.79 \pm 0.28 c$ & $7.11 \pm 0.09 \mathrm{~b}$ & $8.33 \pm 0.31 \mathrm{c}$ \\
\hline Ash & $3.63 \pm 0.13 c$ & $3.33 \pm 0.08 \mathrm{~b}$ & $3.30 \pm 0.02 \mathrm{~b}$ & $3.66 \pm 0.08 \mathrm{c}$ & $3.31 \pm 0.11 \mathrm{~b}$ & $2.94 \pm 0.04 \mathrm{a}$ \\
\hline \multicolumn{7}{|c|}{ Minerals $(\mathrm{mg} / 100 \mathrm{~g})$} \\
\hline Calcium & $9.91 \pm 0.31 \mathrm{c}$ & $8.90 \pm 0$ & $9.89 \pm 0.15 c$ & $10.12 \pm 0.15 c$ & $8.29 \pm 0.19 \mathrm{~b}$ & $5.88 \pm 0.09 \mathrm{a}$ \\
\hline Pot & $\begin{array}{l}546.56 \pm 16.85 \\
d\end{array}$ & $373.82 \pm 8.11 b$ & $490.93 \pm 7.56 \mathrm{c}$ & $495.26 \pm 7.37 \mathrm{c}$ & $497.13 \pm 11.20 \mathrm{c}$ & $182.91 \pm 2.78 \mathrm{a}$ \\
\hline Mag & $25.63 \pm 0.79 \mathrm{e}$ & $20.91 \pm 0.45 b$ & $22.37 \pm 0.34 \mathrm{c}$ & $23.24 \pm 0.35 \mathrm{~cd}$ & $23.76 \pm 0.54 \mathrm{~d}$ & $14.79 \pm 0.22 \mathrm{a}$ \\
\hline Pho & $\begin{array}{l}336.99 \pm 10.39 \\
d\end{array}$ & $290.86 \pm 6.31 b$ & $332.85 \pm 5.12 \mathrm{~d}$ & $308.98 \pm 4.60 \mathrm{c}$ & $280.66 \pm 6.32 b$ & $158.11 \pm 2.40 \mathrm{a}$ \\
\hline Sodium & $53.28 \pm 3.28 \mathrm{~d}$ & $33.49 \pm 1.45 b$ & $21.11 \pm 0.65 \mathrm{a}$ & $31.75 \pm 0.94 b$ & $57.23 \pm 2.58 \mathrm{e}$ & $44.99 \pm 1.37 \mathrm{c}$ \\
\hline Zinc & $7.23 \pm 0.22 \mathrm{~d}$ & $0.71 \pm 0.02 \mathrm{a}$ & $4.38 \pm 0.07 \mathrm{c}$ & $4.47 \pm 0.07 \mathrm{c}$ & $11.92 \pm 0.27 \mathrm{e}$ & $1.29 \pm 0.02 \mathrm{~b}$ \\
\hline Copper & $1.12 \pm 0.03 \mathrm{e}$ & $\mathrm{Nd}$ & $0.13 \pm 0.00 \mathrm{a}$ & $0.88 \pm 0.01 \mathrm{c}$ & $0.97 \pm 0.02 \mathrm{~d}$ & $0.76 \pm 0.01 \mathrm{~b}$ \\
\hline
\end{tabular}

a,bvalues in the same row with different superscripts differ at $5 \%(\mathrm{P}<0.05)$

Table 6: Effect of partial substitution of concentrate diet to leafy vegetables on essential amino acids and vitamins contents of meat rabbit

\begin{tabular}{|c|c|c|c|c|c|c|}
\hline \multirow[b]{2}{*}{ Parameters } & \multicolumn{6}{|c|}{ Treatments } \\
\hline & SMCd & AECd & COCd & IBCd & VUCd & Cd \\
\hline \multicolumn{7}{|c|}{$\begin{array}{l}\text { Essential amino acids } \\
(\mathrm{g} / 100 \mathrm{~g})\end{array}$} \\
\hline Phenylalanine & $0.77 \pm 0.03 \mathrm{~b}$ & $0.71 \pm 0.02 \mathrm{~b}$ & $0.27 \pm 0.02 \mathrm{a}$ & $0.71 \pm 0.05 \mathrm{~b}$ & $0.89 \pm 0.01 \mathrm{c}$ & $0.31 \pm 0.02 \mathrm{a}$ \\
\hline Leucine & $0.81 \pm 0.04 \mathrm{a}$ & $1.52 \pm 0.12 \mathrm{~b}$ & $1.44 \pm 0.04 \mathrm{~b}$ & $0.81 \pm 0.06 \mathrm{a}$ & $1.46 \pm 0.02 \mathrm{~b}$ & $1.44 \pm 0.08 \mathrm{~b}$ \\
\hline Threonine & $1.34 \pm 0.06 \mathrm{~b}$ & $1.50 \pm 0.12 \mathrm{~b}$ & $1.79 \pm 0.06 \mathrm{c}$ & $0.89 \pm 0.07 \mathrm{a}$ & $1.73 \pm 0.03 \mathrm{c}$ & $1.52 \pm 0.09 \mathrm{~b}$ \\
\hline Valine & $0.14 \pm 0.01 \mathrm{~d}$ & $0.07 \pm 0.00 \mathrm{~b}$ & $0.07 \pm 0.00 \mathrm{~b}$ & $0.04 \pm 0.00 \mathrm{a}$ & $0.09 \pm 0.00 \mathrm{c}$ & $0.08 \pm 0.01 b c$ \\
\hline Lysine & $3.71 \pm 0.17 \mathrm{c}$ & $0.94 \pm 0.07 \mathrm{~b}$ & $1.00 \pm 0.03 \mathrm{~b}$ & $0.70 \pm 0.05 \mathrm{a}$ & $0.97 \pm 0.02 \mathrm{~b}$ & $0.98 \pm 0.06 \mathrm{~b}$ \\
\hline Methionine & $2.00 \pm 0.09 \mathrm{c}$ & $0.99 \pm 0.08 \mathrm{a}$ & $0.93 \pm 0.03 \mathrm{a}$ & $1.42 \pm 0.11 \mathrm{~b}$ & $0.95 \pm 0.01 \mathrm{a}$ & $0.84 \pm 0.05 \mathrm{a}$ \\
\hline Tyrosine & $0.89 \pm 0.07 \mathrm{~d}$ & $0.50 \pm 0.02 \mathrm{~b}$ & $0.97 \pm 0.03 \mathrm{~d}$ & $0.15 \pm 0.01 \mathrm{a}$ & $0.65 \pm 0.01 \mathrm{c}$ & $0.95 \pm 0.05 \mathrm{~d}$ \\
\hline \multicolumn{7}{|c|}{ Vitamins $(\mu \mathrm{g} / 100 \mathrm{~g})$} \\
\hline Vitamin A & 0.19 & 0.11 & 0.14 & 0.14 & 0.01 & 0.31 \\
\hline Vitamin E & 280.67 & 147.47 & 153.91 & 146.81 & 151.97 & 273.59 \\
\hline Vitamin B5 & 223.55 & 741.19 & 368.41 & 370.07 & 624.01 & 1425.63 \\
\hline Vitamin B6 & 164.92 & 191.12 & 69.36 & 52.68 & 57.64 & 355.00 \\
\hline Vitamin B9 & 5.50 & 0.72 & 6.15 & 6.16 & 4.15 & 11.46 \\
\hline Vitamin B12 & 11.86 & 14.12 & 6.27 & 10.89 & 13.80 & 13.18 \\
\hline
\end{tabular}

a,bvalues in the same row with different superscripts differ at $5 \%(\mathrm{P}<0.05)$ 


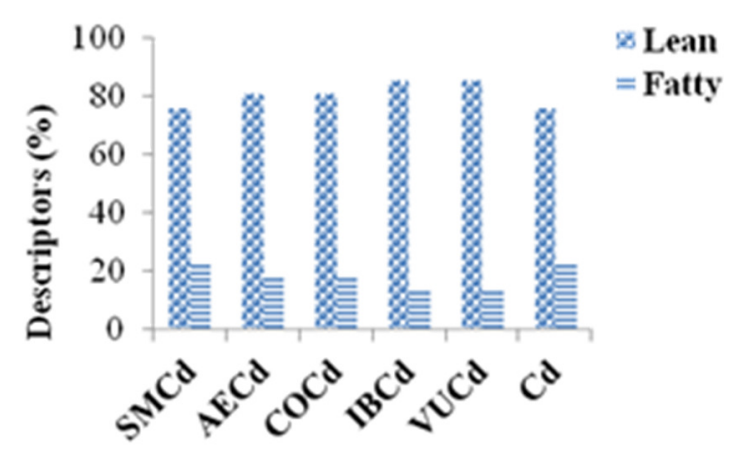

Treatments
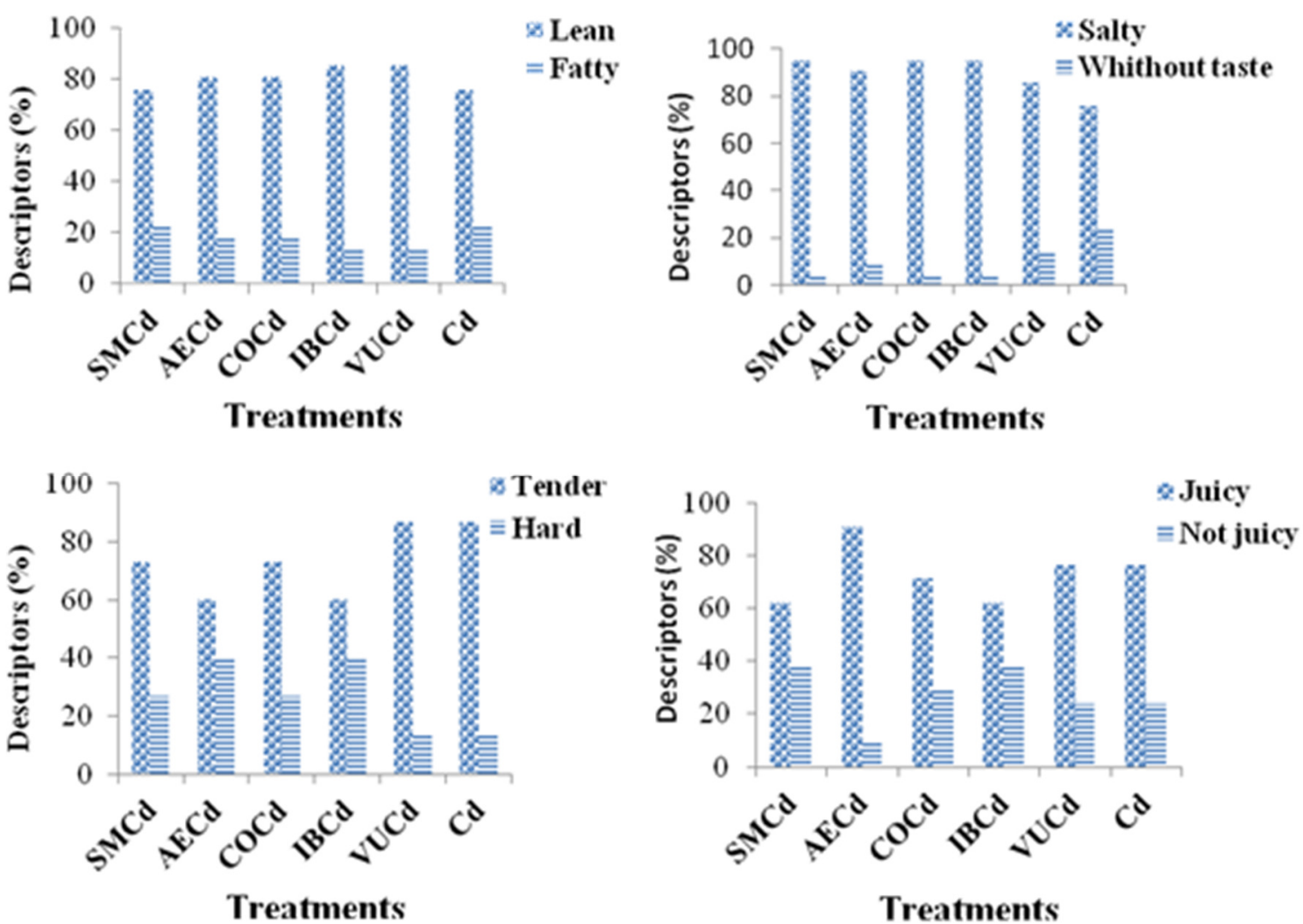

Treatments

Figure 1: Distribution the rabbit meat quality descriptors

Table 7: Average of sensory attributes of meat from rabbits fed with diets Treatments

\begin{tabular}{l|c|c|c|c|c|c}
\hline $\begin{array}{l}\text { Descriptor } \\
\text { s }\end{array}$ & SMCd & AECd & COCd & IBCd & VUCd & Cd \\
\hline Appearance & $2.13 \pm 0.35 \mathrm{a}$ & $2.28 \pm 0.46 \mathrm{a}$ & $2.24 \pm 0.44 \mathrm{a}$ & $2.18 \pm 0.39 \mathrm{a}$ & $2.13 \pm 0.35 \mathrm{a}$ & $2.21 \pm 0.42 \mathrm{a}$ \\
Taste & $2.50 \pm 0.51 \mathrm{ab}$ & $2.24 \pm 0.44 \mathrm{a}$ & $2.21 \pm 0.42 \mathrm{a}$ & $2.72 \pm 0.46 \mathrm{~b}$ & $2.47 \pm 0.51 \mathrm{ab}$ & $2.55 \pm 0.51 \mathrm{ab}$ \\
Tenderness & $1.94 \pm 0.44 \mathrm{a}$ & $2.07 \pm 0.46 \mathrm{ab}$ & $2.00 \pm 0.68 \mathrm{ab}$ & $2.30 \pm 0.47 \mathrm{ab}$ & $2.05 \pm 0.40 \mathrm{ab}$ & $1.94 \pm 0.24 \mathrm{ab}$ \\
Juiciness & $1.53 \pm 0.51 \mathrm{a}$ & $1.68 \pm 0.48 \mathrm{a}$ & $1.59 \pm 0.62 \mathrm{a}$ & $1.60 \pm 0.50 \mathrm{a}$ & $1.74 \pm 0.45 \mathrm{a}$ & $1.76 \pm 0.56 \mathrm{a}$ \\
Overall & $2.00 \pm 0.00 \mathrm{abc}$ & $1.83 \pm 0.38 \mathrm{a}$ & $2.33 \pm 0.49 \mathrm{c}$ & $2.22 \pm 0.43 \mathrm{bc}$ & $\begin{array}{c}2.11 \pm 0.32 \\
\mathrm{acceptability}\end{array}$ & $1.94 \pm 0.42 \mathrm{ab}$ \\
\hline
\end{tabular}

a,b values in the same row with different superscripts differ at $5 \%(\mathrm{P}<0.05)$

The Figure 1 indicated the distribution the rabbit meat quality descriptors obtained after feeding the rabbits. The data showed that the meat was lean, tender and juicy with a salty taste. The rabbit meat from AECd diet and COCd diet presented the lowest averages for the taste descriptors with respectively values of $2.24 \pm 0.44$ and $2.21 \pm 0.42$ and those fed with Ipomoea batatas and concentrate was characterized by highest value (2.72 \pm 0.46$)$. Differences between meats tastes observed may be due to high sodium and potassium content in meat. These high concentrations of potassium and of sodium in meat would be responsible for the salt taste described by the panel. In addition, meat produced from AECd and COCd could be recommended to the persons with hypertension. Overall acceptability was higher for meat rabbit 
fed with industrial diet combined to Corchorus olitorius (2.33 \pm 0.49 ) (table 7 ) whereas those produced by the AECd diet were no accepted by the panel. Lipid content in meat might explain this preference because the juiciness of meat that is important for consumer choice is connected to fat content. It is important to mention that the

\section{CONCLUSION}

The results of this study indicated relationships between nutritional value of feed and carcass characteristics, nutritive value and sensory quality of meat. The richness of nutrients in leafy vegetables is an important asset for increasing these nutrients in meat. The SMCd diet had produced rabbit meat characterized by increase of averages of crude protein, minerals and essential amino acids contents. Except for AECd diet, all meat from experimental diets was

\section{REFERENCES}

Abonyi F. O., Iyi E. O. and Machebe N. S. (2012). Effects of feeding sweet potato (Ipomoea batatas) leaves on growth performance and nutrient digestibility of rabbits. African Journal of Biotechnology Vol. 11(15), pp. 3709-3712.

Acho C.F., Zoué L.T., Akpa E.E., Yapo V.G. and Niamké S.L. (2014). Leafy vegetables consumed in Southern Côte d'Ivoire: a source of high value nutrients. J. Anim. Plant Sci., 20(3): 3159-3170.

Adel E. M., Mohamed M. N, Aziz M. H., Yousef Y. S. and Diaa A. M. (2017) Effect of Substitution Soybean by Blue Green Alga Spirulina platensis on Performance and Meat Quality of Growing Rabbits.American Journal of Food Technology, 12 (1): 51-59

Adeyemo A.A., Adeyemi O.A., Ekunseitan D.A. and Taiwo O.S (2013). Effect of concentrate to forage ratio on the performance and haematological parameters of growing rabbits. Gbobal Journal of Biology, Agriculture \& Health Sciences Vol.2 (2):114-118

AFSSA (2007). French Agency for Food Safety. Protein intake: consumption, quality, meat produced from different diets differ for taste and fibrousness. The difficulty to separate the meat samples according to tenderness and juiciness was reported in the investigations of Omojola (2007) and Kowalska, (2008).

accepted by the tasters. In addition, the association of Solanum melongena leaves and industrial diet could be recommended to the breeders because this system provides a better quality of the meat with sensorial characteristics that were very appreciated by the consumers. Additional work would be required to assess the impact of combination of two of these 5 leafy vegetables on nutritional and sensory quality of the meat.

requirements and recommendations. 461 p.

Akinnusif A. O., Bamgbosea M., Odunaroo E. and Aladea. A. (2007). Carcass characteristics and sensory evaluation of meat from rabbits fed cashew-nut residue based diets. ASSET An International Journal Vol. 7 (1): 19-25

AOAC (1990). Official methods of analysis. Association of Official Analytical Chemists Ed., Washington DC, 684 p.

Blasco A. and Ouhayoun J. (1996). Harmonization of criteria and terminology in rabbit meat research. World Rabbit Science, 4 (2), 93-99.

Dalle Zotte A. (2000). Main factors influencing the rabbit carcass and meat quality. In: Proceedings of the 7th World Rabbit Congress (Valencia, Spain), pp. 1-32.

Dalle Zotte A. and Szendrő Z. (2011). The role of rabbit meat as functional food: a review. Meat Science, 88, 319-331.

De Blas C. and Wiseman J. (2003). The Nutrition of the Rabbit. CABI Publishing, Oxon, UK.

Dokoupilová A., Marounek M., Skřivanová V. and Březina P. (2007). Selenium content 
in tissues and meat quality in rabbits fed selenium yeast. Crech J. Anim. Sci., 52 (6): 165-169.

Duncan B. D. (1955). Multiple Range and Multiple F Tests in Biometrics Vol. 11, No. 1 International Biometric Society. pp. 142.

Fernandez C. and Fraga M. J. (1996). The effect of dietary fat inclusion on growth, carcass characteristics. J. Anim. Sci., 74, pp 2088-2094.

Garza M.T., Lukefahr S.D., Schuster G.L. and McCuistion K.C. (2012). Developing sustainable diets for rabbits: effect of sweet potato forage on growth and feeding traits. World Rabbit Science Association, Proceedings 10 th World Rabbit Congress, Egypt, 781-785.

Gigaud V. and Combes S. (2007). Nutritional advantages of rabbit meat: comparison with other meat products. 12th Cuniculture Research Days, Mans, France, pp.187-190.

ISO (2005). International Organization for Standardization. Animal feeding stuffs Determination of amino acids content, Ed 1.17 p.

Iyeghe-Erakpotobor G.T. and Muhammad I.R. (2008). Intake of tropical grass, legume and legume-grass mixtures by rabbits. Trop. Grasslands, 42: 112-119.

Kimsé M., Soro D., Bléyéré M. N., Yapi J.N. and Fantodji A. (2013). Contribution of tropical green forage, Centrosema pubescens, in addition to pellets: effect on the growth and health performance of the rabbit Oryctolagus cuniculus. Int. J. Biol. Chem. Sci., 7: 1234-1242.

Kimsé M., Gnanda B.I., Beugré G.A.M., Bodji N'guessan C. and Fantodji A. (2014). Effect of associated using of commercial feed supplementation and green forage on rabbit (Oryctolagus cuniculus) growth and health. Scientia Agriculturae 6 (3): 114119

Kowalska D. (2008). Effect of dietary supplementation with rapeseed and fish oil mixture and antioxidant on rabbit meat quality. Meat Quality and Safety, 9th World Rabbit Congress - June 10-13, Verona - Italy, 1372-1376.

Kpodékon M., Youssao A. K. I., Koutinhouin G. B., Baba I. L., Dessou J. M. and Djago Y. (2009). Effect of granulation on growth performance, feed efficiency and viability of young rabbits under tropical conditions. Revue Elev. Méd. Vét. Pays Trop., 62: 75-80.

Lebas F. (1989). Nutritional requirements of rabbits: bibliography and perspectives. Cuni-Sci., 5 : 1-28.

Lebas F., Coudert P., De Rochambeau H. and Thébault R.G. (1996). The rabbit: breeding and pathology. FAO Animal Production and Health Collection No19, Rome. p. 143.

Martignon M.H., Combes S. and Gidenne T. (2010). Digestive physiology and hindgut bacterial community of the young rabbit Oryctolagus cuniculus: Effects of age and short-term intake limitation. Comparative Biochemistry and Physiology-Part A. Mol. Integr. Physiol., 156: 156- 162.

Nguyen Van T. and Nguyen Thi K.D. (2008). Effect of water spinach and sweet potato vine associated with 2 other natural plants, on growth performance, carcass values and economic return of growing crossbred rabbits in the Mekong Delta of Vietnam. 9th World Rabbit Congress June 10-13 - Verona - Italy -6 p.

Omojola A.B. (2007). Effect of Delayed Bleeding on Carcass and Eating Qualities of Rabbit Meat Pakistan Journal of Nutrition, 6 (5): 438-442,

Ouhayoun J., Poujardieu B., and Delmas D. (1986). Study of the growth and body composition of rabbits after 11 weeks of age. J. Rech. cunic., 24 p.

Ouhayoun J. and Delmas D. (1983). Comparative valorization of different levels of feed by rabbits selected for growth and traditional rabbits. II/ Study of nitrogen composition and energetic metabolism of Longissimus dorsi and 
Biceps femoris muscles. Ann. Zoo- tech., 32, 277-286.

Ouhayoun J., Poujardieu B., and Delmas D. (1986). Study of the growth and body composition of rabbits after 11 weeks of age. J. Rech. cunic., 24 p.

Oulai P., Zoué L., Mégnanou, R.M. Doué, G., and Niamké S. (2014). Proximate composition and nutritive value of leafy vegetables consumed in northern Côte d'Ivoire. Eur. Sci. J., 10 (6): 212-227.

Perez J.M., Lebas F., Gidenne T., Maertens L., Xiccato G., Parigi-Bini R., Dalle Zotte A., Cossu M.E., Carazzolo A., Villamide J., Carabano R., Fraga M., Ramos M.A., Cervera C., DeBlas E., Fernandez J., Falcao E., Cunha L. and Bengala F. J. (1995). European reference method for in vivo determination of diet digestibility in rabbits. World Rabbit Sci., 3: 41-43.

Petsko G. A. and Ringe D. (2008). Structure and function of proteins, Bruxelles, De Boeck

Université, First ed., 212 p.

Ph. Eur. (2014). European pharmacopoeia, 8th Edition, tome 1, p: 96-97

Renouf B. and Offner A. (2007). Effect of the energy level and distribution period of the feed on rabbit growth, mortality and yield at slaughter.2th Cuniculture Research Days, 27-28 November, Le Mans, France. 4p

Simonová M. P., Chrastinová L., Mojto J., Lauková A., Szabóová R. and Rafay J. (2010). Quality of rabbit meat and phytoadditives. Czech J. Food Sci., 28: 161-167.

Suttle N.F. (2010). Mineral Nutrition of Livestock. 4th ed. CAB International, Oxfordshire, UK

Trocino A., Xiccato G., Queaque P.I. and Sartori A, (2000). Feeding plans at different protein levels: effects on growth performance, meat quality and nitrogen excretion in rabbits.

Journal of the World Rabbit Science Association, Volume 8, pp 467-473

Yao K. F. Otchoumou K. A. Wognin L.R.M.F., Konan K.A. and Niamké S. (2016). Growth Parameters, Protein
Digestibility and Health Status of Rabbit Oryctolagus Cuniculus Fed with Palatable Leafy Vegetables. European Scientific Journal vol.12, $17 \mathrm{p}$

Zoro, A. F., Zoué, L. T., Kra, S. A. K, Yépié, A. $\mathrm{E}$ and Niamké, S. L., (2013). An Overview of Nutritive Potential of Leafy Vegetables Consumed in Western Côte d'Ivoire. Pak. J. Nutr. 12 (10): 949-956. 